\title{
The Prevalence and Characteristics of Physical Therapy Pro Bono Services Involving Doctor of Physical Therapy Students
}

\author{
Catherine E. Crandell \\ Bellarmine University, ccrandell@bellarmine.edu \\ Jill D. Black \\ Widener University, jdblack@widener.edu \\ Robin L. Dole \\ Widener University, rldole@widener.edu \\ Kerstin M. Palombaro \\ Widener University, kpalombaro@widener.edu
}

Follow this and additional works at: https://nsuworks.nova.edu/ijahsp

Part of the Physical Therapy Commons

This Manuscript has supplementary content. View the full record on NSUWorks here: https://nsuworks.nova.edu/ijahsp/vol18/iss2/13

\section{Recommended Citation \\ Crandell CE, Black JD, Dole RL, Palombaro KM. The Prevalence and Characteristics of Physical Therapy Pro Bono Services Involving Doctor of Physical Therapy Students. The Internet Journal of Allied Health Sciences and Practice. 2020 Jan 01;18(2), Article 13.}

This Manuscript is brought to you for free and open access by the College of Health Care Sciences at NSUWorks. It has been accepted for inclusion in Internet Journal of Allied Health Sciences and Practice by an authorized editor of NSUWorks. For more information, please contact nsuworks@nova.edu. 


\title{
The Prevalence and Characteristics of Physical Therapy Pro Bono Services Involving Doctor of Physical Therapy Students
}

\begin{abstract}
Purpose: The offering of pro bono services has been a historical practice in a number of professions including law and medicine. Medical literature suggests pro bono services provide a vital safety net for individuals who are underinsured or uninsured. Medical students commonly participate in pro bono services, however, little is known about doctor of physical therapy (DPT) student involvement. The purpose of this study was to conduct a survey of physical therapy (PT) programs accredited or in candidacy in the United States to determine the prevalence and characteristics of pro bono services involving DPT students. Method: A 30-item electronic survey was sent to 101 individuals representing accredited or in candidacy PT programs thought to be involved with students in the delivery of PT pro bono services. Data were analyzed using SPSS. Frequency counts and percentages were used to describe prevalence and characteristics of current pro bono services. Results: The response rate was $71.3 \%$ with 72 unique institutions completing the survey. Sixty-six institutions reported student involvement in pro bono services and an additional five with plans to start services in the future. The survey yielded data related to institution demographics, general pro bono service characteristics, clinic operations, student leadership, interprofessional interactions and curricular links. Conclusions: Pro bono services involving DPT students are on the rise and the literature points to the importance of PT pro bono services as a rehabilitative safety net and as a creative pedagogy for student professional development. Provision of PT pro bono services may promote public awareness of PT while serving as a catalyst to actualize altruism and social responsibility Core Value expression in DPT students.
\end{abstract}

\section{Author Bio(s)}

Catherine E. Crandell, PT, DPT, MDiv, is Associate Professor and Director of Service-Learning Clinics, Doctor of Physical Therapy Program at Bellarmine University.

Jill D. Black, PT, DPT, EdD, is Associate Dean and Program Director, Institute for Physical Therapy Education at Widener University.

Robin L. Dole, PT, DPT, EdD, PCS, is Dean, School of Human Services Professions and Professor of Physical Therapy, Institute for Physical Therapy Education at Widener University.

Kerstin M. Palombaro, PT, PhD, CAPS, is Associate Professor and Community Engagement Coordinator, Institute for Physical Therapy Education at Widener University. 


\title{
1IVAHSP \\ The Internet Joumnal of Allied Health Sciences and Practice \\ Dedicated to allied health professional practice and education
}

Vol. 18 No. 2 ISSN 1540-580X

\section{The Prevalence and Characteristics of Physical Therapy Pro Bono Services Involving Doctor of Physical Therapy Students}

\author{
Catherine E. Crandell 1 \\ Jill D. Black² \\ Robin L Done ${ }^{2}$ \\ Kerstin M. Palombaro²
}

1. Bellarmine University

2. Widener University

United States

\begin{abstract}
Purpose: The offering of pro bono services has been a historical practice in a number of professions including law and medicine. Medical literature suggests pro bono services provide a vital safety net for individuals who are underinsured or uninsured. Medical students commonly participate in pro bono services, however, little is known about doctor of physical therapy (DPT) student involvement. The purpose of this study was to conduct a survey of physical therapy (PT) programs accredited or in candidacy in the United States to determine the prevalence and characteristics of pro bono services involving DPT students. Method: A 30item electronic survey was sent to 101 individuals representing accredited or in candidacy PT programs thought to be involved with students in the delivery of PT pro bono services. Data were analyzed using SPSS. Frequency counts and percentages were used to describe prevalence and characteristics of current pro bono services. Results: The response rate was $71.3 \%$ with 72 unique institutions completing the survey. Sixty-six institutions reported student involvement in pro bono services and an additional five with plans to start services in the future. The survey yielded data related to institution demographics, general pro bono service characteristics, clinic operations, student leadership, interprofessional interactions and curricular links. Conclusions: Pro bono services involving DPT students are on the rise and the literature points to the importance of PT pro bono services as a rehabilitative safety net and as a creative pedagogy for student professional development. Provision of PT pro bono services may promote public awareness of PT while serving as a catalyst to actualize altruism and social responsibility Core Value expression in DPT students.
\end{abstract}

Keywords: pro bono, physical therapy, doctor of physical therapy students, core values 


\section{INTRODUCTION}

The offering of pro bono services has been a historical practice in a number of professions including law and medicine..$^{1-6}$ The practice of "cause lawyers" in which lawyers would provide services to underserved clients or valued causes without charge dates back to the $1700 s^{1,2}$ In the 1960s, the law profession institutionalized this value with a call for all practicing attorneys to deliver a quota of pro bono hours per year.,3 Historically, this is the first professional reference to pro bono or pro bono publico, a Latin phrase meaning "for the public good."1

Like the law profession, the medical profession has traditionally acknowledged the importance of delivering care to those unable to afford services. The first reported medical free clinic opened its doors in 1967. ${ }^{7}$ Between 1967 and 1969, a total of 59 medical free clinics were in operation and 60 new centers planned to open in 1970.8 The majority of clients served by these early free clinics were runaway youths and those caught in drug addiction. 5,8 The American Medical Association (AMA) did not formally endorse free clinics until 1994.5,6 The 1996 Health Insurance Portability and Accountability Act further supported the free clinic movement by calling for the extension of medical malpractice protection to cover volunteer free clinic healthcare professionals. ${ }^{9}$ In 2010, Darnell conducted a survey to determine the presence and characteristics of free medical clinics. Free clinics typically operate outside the government established Federally Qualified Health Centers that are intended to serve as a safety net. ${ }^{9}$ Darnell used an extensive snowball sampling technique and a strict operational definition to identify 1188 free clinics in the United States. Her survey yielded responses from 1007 of the 1188 free medical clinics. Most of the medical free clinics were founded in the 1990s with a mean start year of 1995. Characteristics of onsite staff listed in her survey encompassed a variety of professional services, but neither physical therapists nor physical therapy (PT) were listed in the survey. ${ }^{9}$

Twenty-two percent of the free clinics surveyed by Darnell were associated with a university or medical school. ${ }^{9}$ Simpson and Long conducted a survey in 2005 of all medical schools within the Association of American Medical Colleges (AAMC) and found that at least 49 of 124 (39.5\%) had a student-run free clinic with medical students both administrating the clinic and delivering clinical care to underserved patients under the supervision of licensed mentors. ${ }^{10}$ Smith et al repeated a similar study and found that of the 141 accredited AAMC medical schools in 2014, 106 (75.2\%) were operating student-run free clinics. ${ }^{11}$ The number of AAMC medical schools with student-run free clinics had more than doubled between 2005 and 2014. The literature contains several articles that describe various models of student-run free clinics operating from medical schools. Many of these clinics are interdisciplinary, but only a few report the integration of PT services. ${ }^{12-20}$

Physical therapy is a much younger profession in comparison to law and medicine; however, the profession has adopted a similar commitment to social responsibility and altruism as evidenced in the profession's statement of Core Values and their Code of Ethics. ${ }^{21,22}$ Altruism specifically calls upon PT professionals to be involved in pro bono care or care for the public good. As a relatively new profession, PT has the opportunity to define what "care for the public good" looks like for the profession. A review of the literature reveals examples where DPT students are participating in pro bono service under licensed supervision to underserved community members. ${ }^{18-20,23,24}$ Overall, little is known about the prevalence or characteristics of pro bono services with DPT student involvement. Therefore, the purpose of this study was to conduct a survey of PT programs accredited or in candidacy by the Commission on Accreditation in Physical Therapy Education (CAPTE) in the United States to determine the prevalence and characteristics of pro bono services involving DPT students.

\section{METHODS}

\section{Study Design}

The researchers developed and administered a web-based survey instrument to explore the prevalence and characteristics of PT programs with pro bono services involving students.

\section{Participants}

The recruitment strategy was multi-faceted and involved exploring databases of pro bono contacts across the American Physical Therapy Association (APTA) Health Policy \& Administration (HPA) Pro Bono Catalyst Group and The Pro Bono Network, two organizations where physical therapist faculty and students conducting pro bono services connect. In an attempt to be exhaustive, an informal email inquiry was sent to the 242 US PT Program Directors of accredited or in candidacy programs, asking if their program offered pro bono services involving students. The researchers merged positive responses with the existing contact lists resulting in a total of 101 potential participants for the study. See Figure 1 for a depiction of the recruitment strategy. 


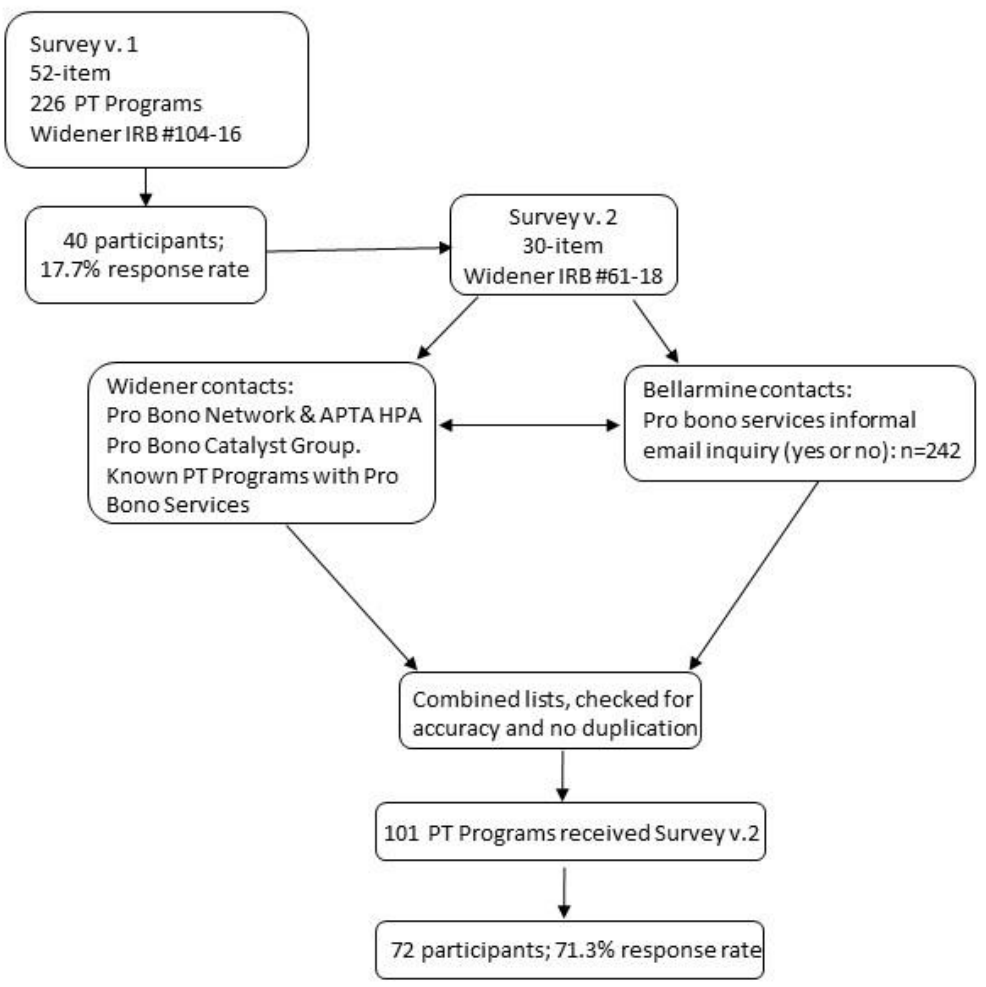

Figure 1. Study Recruitment Strategy

The researchers operationally defined PT pro bono service as PT services offered at little or no cost to individuals who are uninsured or underinsured, and this included services delivered by DPT students who require the supervision of a licensed physical therapist. The Institutional Review Board of Widener University approved this study (\#61-18). Respondents provided informed consent by reading a statement at the beginning of the survey and checking yes or no for survey participation. The rights of all study participants were protected.

\section{Materials}

The researchers previously piloted a 52-item survey and based on feedback, revised and clarified survey questions and consolidated the number of questions to 30 -items. The electronic Qualtrics survey contained demographic questions followed by a series of multiple-choice questions to identify the prevalence and characteristics of the pro bono service opportunities available to DPT students in CAPTE accredited or in candidacy academic programs in the United States.

\section{Procedure}

The Qualtrics survey was emailed in March 2018 to the 101 PT program contacts identified as being involved in the delivery of pro bono involving DPT students. The researchers resent the survey monthly via Qualtrics for two additional months to those who had not yet responded. The researchers closed the survey in June of 2018. Data were analyzed using SPSS version 23. Frequency counts and percentages were used to describe prevalence of pro bono services.

\section{RESULTS}

The response rate was $71.3 \%$ with 72 unique institutions completing the survey. Of the respondents, 68 programs were accredited, and four were in candidacy. See Table 1 for demographic characteristics. 
Table 1. Demographic Characteristics of Institutions Offering Pro Bono Services

\begin{tabular}{|l|c|c|}
\hline Demographic Characteristic (n=72) & $\mathrm{n}$ & $\%$ \\
\hline Type of Institution & 33 & 45.8 \\
Public & 23 & 32.0 \\
Faith-based private & 16 & 22.2 \\
Non-faith-based private & & \\
\hline CAPTE Regions & 21 & 29.2 \\
South Atlantic (DE, DC, FL, GA, MD, NC, PR, SC, VA, WV) & 12 & 16.7 \\
Middle Atlantic (NJ, NY, PA) & 12 & 16.7 \\
West North Central (IA, KS, MN, MO, NE, ND, SD) & 7 & 9.7 \\
East North Central (IL, IN, MI, OH, WI) & 6 & 8.3 \\
Mountain (AZ, CO, ID, MT, NV, NM, UT, WY) & 5 & 6.9 \\
Pacific (AK, CA, HI, OR, WA) & 4 & 5.6 \\
New England (CT, ME, MA, NH, RI, VT) & 4 & 5.6 \\
East South Central (AL, KY, MS, TN) & 1 & 1.4 \\
West South Central (AR, LA, OK, TX) & & \\
\hline
\end{tabular}

Of the 72 responses received, sixty-six respondents (91.7\%) reported their institution provided opportunities for PT pro bono services that involved DPT students. Four programs stated that they did not currently, but were planning to start services within the next year. One program stated that they were considering starting services in the near future. One program did not provide opportunities for PT pro bono services to be delivered by DPT students.

\section{Settings}

For respondents who currently have pro bono services offered by DPT students, the number of unique PT pro bono service opportunities and/or settings provided ranged from 1-11. Respondents with more than one pro bono setting were asked to identify and consider their primary pro bono setting as they answered the remaining survey questions. A majority of the services were delivered to local communities with approximately one-third also serving regional and international communities. Programs further identified the different types of settings for their pro bono PT opportunities and outpatient clinics were the most frequently cited. See Table 2 for prevalence and type of service settings.

Table 2. Prevalence of Unique Physical Therapy Pro Bono Service Opportunities by Setting

\begin{tabular}{|l|c|c|}
\hline Setting (n=66) (select all that apply) & $\mathrm{n}$ & $\%$ \\
\hline Outpatient Clinic & 41 & 62.1 \\
\hline Community Setting (i.e. homeless shelter, church, community center) & 30 & 45.5 \\
\hline Academic Classroom or Lab & 27 & 40.9 \\
\hline International Setting & 20 & 30.3 \\
\hline $\begin{array}{l}\text { Other (included international missions, university athletic training rooms, farm workers, a dance } \\
\text { company, or a free clinic) }\end{array}$ & 16 & 24.2 \\
\hline Federally Funded Community Health Center & 13 & 19.7 \\
\hline Mobile Clinic & 4 & 6.1 \\
\hline Hospital Setting & 3 & 4.5 \\
\hline Elementary, Middle, or High School Setting & 3 & 4.5 \\
\hline
\end{tabular}

\section{Clinic Operations}

A majority of the PT pro bono services have been operating between one and eight years. Services tended to be offered during the daytime hours and two times per week throughout the calendar year. Very few pro bono services asked for any fee for service provided. See Table 3 for operational characteristics.

\section{Educational and Curricular Considerations}

The majority of programs (95.5\%) identified that students delivered the PT services with faculty or other licensed physical therapists supervising. Three programs stated that faculty led the treatment, while students assisted or observed. With respect to administration of PT pro bono services, 28 programs (42.2\%) used a combination of student-led and faculty-led administration, 27 programs $(40.9 \%)$ had a student-led model and 11 programs (16.7\%) had a faculty-led model. 
Table 3. Operational Characteristics

\begin{tabular}{|c|c|c|}
\hline Operational Characteristics & $\mathrm{n}$ & $\%$ \\
\hline $\begin{array}{l}\text { Length of Time in Operation }(n=68) \\
<1 \text { year } \\
1-2 \text { years } \\
3-5 \text { years } \\
6-8 \text { years } \\
9-11 \text { years } \\
12-15 \text { years } \\
16-20 \text { years } \\
>20 \text { years }\end{array}$ & $\begin{array}{c}6 \\
12 \\
17 \\
10 \\
5 \\
8 \\
7 \\
3\end{array}$ & $\begin{array}{r}8.8 \\
17.6 \\
25.0 \\
14.7 \\
7.4 \\
11.8 \\
10.3 \\
4.4\end{array}$ \\
\hline $\begin{array}{l}\text { Time of Day }(n=88) \text { (select all that apply) } \\
\text { During the day } \\
\text { Evenings } \\
\text { Weekends } \\
\text { Other }\end{array}$ & $\begin{array}{c}45 \\
36 \\
6 \\
1\end{array}$ & $\begin{array}{c}51.1 \\
40.9 \\
6.8 \\
1.1\end{array}$ \\
\hline $\begin{array}{l}\text { Duration of Services }(\mathbf{n}=68) \\
\text { Calendar Year } \\
\text { Fall and Spring Semesters of Academic Year } \\
\text { Less than one semester } \\
\text { One Semester of the Year } \\
\text { Two weeks }\end{array}$ & $\begin{array}{c}38 \\
21 \\
4 \\
3 \\
2\end{array}$ & $\begin{array}{c}55.9 \\
30.9 \\
5.9 \\
4.4 \\
2.9\end{array}$ \\
\hline $\begin{array}{l}\text { Frequency of Services }(n=56) \text { (select all that apply) } \\
\text { Twice/week } \\
\text { Once/week } \\
\text { Three/week } \\
\text { Four/week } \\
\text { Twice/month } \\
\text { Five/week } \\
\text { Once/month } \\
\text { Other }\end{array}$ & $\begin{array}{l}24 \\
19 \\
4 \\
3 \\
1 \\
1 \\
1 \\
3\end{array}$ & $\begin{array}{l}42.9 \\
33.9 \\
7.1 \\
5.4 \\
1.8 \\
1.8 \\
1.8 \\
5.4\end{array}$ \\
\hline $\begin{array}{l}\text { Fee-for-Service }(n=9) \\
\$ 5.00 / \text { visit } \\
\$ 15.00 / v i s i t \\
\$ 10.00 / v i s i t \text { for a max of } \$ 30 / \text { episode } \\
\$ 50.00 \text { with fee waivers available } \\
\text { donations if offered } \\
\text { students cover per diem for international travel \& fund raise } \\
\text { Other, not specified }\end{array}$ & $\begin{array}{l}2 \\
2 \\
1 \\
1 \\
1 \\
1 \\
1\end{array}$ & $\begin{array}{l}22.2 \\
22.2 \\
11.1 \\
11.1 \\
11.1 \\
11.1 \\
11.1\end{array}$ \\
\hline
\end{tabular}

Over half of the respondents (54.2\%) noted interprofessional pro bono services alongside PT services. A total of 22 disciplines were represented in this survey with occupational therapy and medicine cited most frequently followed by nursing and social work.

Provision of PT pro bono services was required in approximately two-thirds of the total responses (63.2\%) with voluntary participation (30.9\%) noted in the other programs. For the required student involvement, most pro bono services were either linked to a mandatory course (39.7\%), embedded throughout the curriculum (20.6\%), or an extension of a course or lab $(5.9 \%)$. Nineteen programs $(27.9 \%)$ identified some "other" linkage such as volunteer, non-credit bearing co-curricular activity, volunteer extracurricular activity, or participation that counted toward community service or interprofessional education requirements. See Table 4 for additional details related to educational and curricular considerations. 
Table 4. Curricular and Educational Characteristics

\begin{tabular}{|c|c|c|}
\hline Curricular and Educational Characteristics & $\mathbf{n}$ & $\%$ \\
\hline \multicolumn{3}{|l|}{ Student Clinical Role $(n=66)$} \\
\hline Students lead treatment with faculty observing & 63 & 95.5 \\
\hline Faculty lead treatment with students assisting or observing & 3 & 4.5 \\
\hline \multicolumn{3}{|l|}{ Faculty-to-Student Supervision Ratio (n=68) } \\
\hline $1: 1$ & 1 & 1.5 \\
\hline $1: 2$ & 24 & 35.3 \\
\hline $1: 3$ & 11 & 16.2 \\
\hline $1: 4$ & 13 & 19.1 \\
\hline $1: 5$ & 3 & 4.4 \\
\hline $1: 6$ & 5 & 7.4 \\
\hline $1: 7$ & 1 & 1.5 \\
\hline $1: 8$ & 1 & 1.5 \\
\hline Other & 9 & 13.2 \\
\hline \multicolumn{3}{|l|}{ Student Administrative Role $(\mathrm{n}=66)$} \\
\hline Combination of Student-led and Faculty-Led & 28 & 42.4 \\
\hline Student-Led & 27 & 40.9 \\
\hline Faculty-Led & 11 & 16.7 \\
\hline \multicolumn{3}{|l|}{ Length of Time of Student Leadership Component $(n=55)$} \\
\hline$<1$ year & 8 & 14.5 \\
\hline $1-2$ years & 13 & 23.6 \\
\hline $3-5$ years & 17 & 30.9 \\
\hline $6-8$ years & 8 & 14.5 \\
\hline $9-11$ years & 4 & 7.3 \\
\hline $12-15$ years & 3 & 5.5 \\
\hline $16-20$ years & 1 & 1.8 \\
\hline$>20$ years & 1 & 1.8 \\
\hline \multicolumn{3}{|l|}{ Interprofessional Opportunities ( $n=39$ ) (check all that apply) } \\
\hline Occupational Therapy & 20 & 51.3 \\
\hline Medicine & 20 & 51.3 \\
\hline Nursing & 16 & 41.0 \\
\hline Social Work & 13 & 33.3 \\
\hline Nutrition & 8 & 20.5 \\
\hline Speech \& Language Pathology & 8 & 20.5 \\
\hline Psychology & 7 & 17.9 \\
\hline Dental & 7 & 17.9 \\
\hline Laboratory Technicians & 4 & 10.3 \\
\hline Education & 3 & 7.7 \\
\hline Respiratory Therapy & 1 & 2.6 \\
\hline \multicolumn{3}{|l|}{ OTHER } \\
\hline Pharmacy & 9 & 23.1 \\
\hline Physicians Assistants & 4 & 10.3 \\
\hline Athletic Trainers & 1 & 2.6 \\
\hline Legal & 1 & 2.6 \\
\hline Biomedical Informatics & 1 & 2.6 \\
\hline Exercise Science & 1 & 2.6 \\
\hline Public Health & 1 & 2.6 \\
\hline Language Interpreters & 1 & 2.6 \\
\hline Physical Therapy Assistants & 1 & 2.6 \\
\hline Prosthetics \& Orthotics & 1 & 2.6 \\
\hline Patient Advocates & 1 & 2.6 \\
\hline \multicolumn{3}{|l|}{ Student Involvement in Delivery of Pro Bono Services $(n=68)$} \\
\hline Required & 43 & 63.2 \\
\hline Voluntary & 21 & 30.9 \\
\hline Neither voluntary nor required & 4 & 5.9 \\
\hline
\end{tabular}

(C) The Internet Journal of Allied health Sciences and Practice, 2020 


\begin{tabular}{|c|c|c|}
\hline \multicolumn{3}{|l|}{ Link to Curriculum $(\mathrm{n}=68)$} \\
\hline Linked to a mandatory course & 27 & 39.7 \\
\hline Embedded throughout the curriculum & 14 & 20.6 \\
\hline Extension of a course or lab & 4 & 5.9 \\
\hline Linked to an elective course & 4 & 5.9 \\
\hline Other & 19 & 27.9 \\
\hline
\end{tabular}

\section{DISCUSSION}

This was the first reported study examining the prevalence and characteristics of PT pro bono services involving DPT students. The recruitment process for this study identified that 101 of $242(41.7 \%)$ of accredited or developing PT programs have pro bono services involving DPT students. ${ }^{25}$ In comparison, Smith and colleagues recruitment process in 2014 found that $75.2 \%$ of medical schools accredited within AAMC operated student-run free clinics and this number had more than doubled since $2005 .{ }^{11}$ Physical therapy pro bono services involving DPT students is relatively new with the highest number of respondents beginning operations 3-5 years ago (25\%) and the second highest within the last 1-2 years (17.6\%). Three reported offering pro bono PT services involving DPT students for more than 20 years, thereby suggesting these services may have started in the mid- to late 1990 s, the same timeframe when the medical free clinic movement gained momentum. While PT programs fall short of pro bono service involvement compared to medical schools, this study suggests that the development of pro bono service opportunities for DPT students is on the rise.

The characteristics of clinic operations and DPT student involvement are interesting to compare to the student-run medical clinics. Most PT pro bono services were offered one to two times per week (76.8\%). The medically based clinics most often operated once a week. ${ }^{9-11}$ Approximately one-half of the PT pro bono services were offered throughout the calendar year $(55.9 \%)$; while approximately one-third operated during the academic year only $(30.9 \%)$. In the medical literature, $85.7 \%$ of the student-run free clinics were open year-round. ${ }^{11}$ Only 3 of 66 PT pro bono service programs indicated that faculty led the treatment with DPT students observing (4.5\%). All others (95.5\%) had students delivering the service with faculty or other licensed physical therapists providing supervision. The medical profession had $100 \%$ of their students delivering the service..$^{10,11}$

Approximately two-thirds of PT pro bono services captured in this survey were curricular-based with $66.2 \%$ indicating mandated service while the medical pro bono services tended to be voluntary student participation.9,11 Smith et al reported the mean percentage of medical student involvement in the clinics was $57.8 \%$, indicating that only approximately one-half of the medical students participated throughout their four years of medical school. Furthermore, Smith et al reported that no academic credit was available in $53.1 \%$ of the reporting schools; service could count as a clinical elective in $24.7 \%$ of the cases and as a preclinical elective $11.1 \%$ of the time. In only $6.2 \%$ of the schools was it a part of the preclinical core curriculum and $4.9 \%$ as part of the clinical core curriculum. ${ }^{11}$

One of the earliest medical student-run free clinics began in 1990 as a joint effort between the University of California at Berkley and the University of California San Francisco undergraduate and graduate students and faculty. ${ }^{26}$ Named "The Suitcase Clinic," this student-run clinic was modeled after the first free medical clinic from 1967. ${ }^{7}$ In addition, a Society of Student Run Free Clinics (SSRFC) was formed to foster student leadership and provide networking opportunities at annual conferences. ${ }^{27}$ Currently, there are 96 registered clinic memberships in the SSRFC. Simpson indicated in 2005 that the average time of operation for StudentRun Free Clinics was 7.4 years, equating an average onset of operation between 1997 and 1998.10 Physical therapy programs have been slower to trust their DPT students with clinic leadership, but this study shows that $83.3 \%$ of the respondents have allowed some element of student administrative responsibility. Most report student leadership involvement evolving in the past one to eight years (69.1\%). Physical therapy faculty seem to be embracing the idea that their DPT students have just as much capacity for administration and leadership as the medical students. The Pro Bono Network, founded by DPT students, exists with a mission similar to the SSRFC: to foster student leadership and provide networking opportunities with annual conferences across the country. ${ }^{28}$

The primary setting for the PT pro bono service was an outpatient clinic followed by a community setting such as a church, homeless shelter, or community center. Simpson and Long found the most common setting for the student-run free clinics to be a homeless shelter or community center. ${ }^{10}$ In the 2014 study by Smith et al, the authors reported that the student-run free medical clinics were most often operating from a community clinic $(50.6 \%)$ followed by a medical office building (28.2\%), a church (21.2\%), or a homeless shelter (20\%). ${ }^{11}$ With the crossover of settings between the student-run free clinics and the PT pro bono services, one would hope to see evidence of PT services within the medical free clinics, however, this was not readily apparent from the literature or from this study. In general, the medical pro bono clinics reported in the literature tended to be more interdisciplinary $(72.9 \%)$ than the PT pro bono services. ${ }^{9,11}$ Approximately one-half of the PT programs (54.2\%) identified interprofessional 
collaborative practice opportunities within their pro bono service, and they most frequently interfaced with occupational therapy, medicine, nursing, and social work professionals. However, in Simpson and Long's 2005 survey, PT was not listed as a service at all. In Smith's 2014 survey, physical therapists were not named on the long list of interprofessional partners, and yet "physical therapy" did make the list of services offered in $22.2 \%$ of the surveyed clinics. Likewise, Darnell's 2010 survey of medical free clinics did not identify PT as a service or professional collaborator in the clinics. In order to better align with the APTA's Core Values and Code of Ethics, the PT profession could improve in its participation, visibility, and leadership in providing interprofessional care for uninsured and underinsured communities.

The medical literature suggests pro bono services provide a vital safety net for individuals who are underinsured or uninsured. .-11 $^{-11}$ A summary report from The Synthesis Project identified many factors affecting the cost-effectiveness of preventive care. Preventive health care may be cost-effective even if it does not demonstrate overall health care cost-savings. ${ }^{29}$ Medical pro bono services contained within health professions education may contribute to overall cost-savings and improved health, especially if these services focus on provision of preventive care. Similar to medical pro bono clinics, the findings of this study show the potential for PT pro bono services to positively contribute to health and well-being of underserved populations. Physical therapy pro bono services that not only address acute and chronic conditions but also focus on preventative care may add another safety net layer for individuals who are underinsured or uninsured.

\section{LIMITATIONS AND FUTURE RESEARCH}

One limitation of this research was that it targeted only academic programs; not PT pro bono services that occur unrelated to academic institutions. Additional limitations of this study included the collection of data by self-report and the variable number of responses per item. Including survey information on the types of conditions treated may have added descriptive value and should be considered in future research. While this study has provided a starting point for describing the prevalence and characteristics of PT pro bono services, follow-up focus interviews would be beneficial to further clarify the current landscape of pro bono PT services involving DPT students.

\section{CONCLUSION}

Pro bono services within the PT profession are relatively new compared to the medical and legal professions but are on the rise. Provision of PT pro bono service is an APTA Professional Core Value under altruism and is a tenet in the Professional Code of Ethics. ${ }^{21,22}$ The provision of PT pro bono services may promote public awareness of the profession of PT while serving as a catalyst to actualize altruism and social responsibility Core Value expression in DPT students. ${ }^{30-35}$

Previous literature around PT pro bono services have demonstrated student development in the following areas: leadership; communication and clinical skills; interpersonal skills; and Professional Core Value expression.30-35 Additional recent literature includes improvement in client outcomes such as quality of life, pain measures, and function. ${ }^{23,24,36}$

Pro bono PT services involving DPT students are on the rise, and the literature points to the importance of PT pro bono services as a rehabilitative safety net and as a creative pedagogy for student professional development. The PT profession could increase in its visibility and leadership via participation in interprofessional pro bono practice. Additional research is warranted to better understand PT pro bono service with the ultimate goal of identifying promising practices for programs, communities, policies, students, and the profession.

\section{References}

1. $\quad$ Coir M. Pro bono and access to justice in america: A few historical markers. Michigan Bar Journal. 2011;90:54-55.

2. Pearce RG. The lawyer and public service. Am Univ J Gend Soc Policy Law. 2001;9(1):171-178.

3. Anand R, Nicoletta S. Fostering pro bono service in the legal profession: Challenges facing the pro bono ethic. Paper presented at: Ninth Colloquium on the Legal Profession. 2007; Toronto, Canada.

4. What is pro bono? Retrieved at: https://www.law.georgetown.edu/experiential-learning/pro-bono-communityservice/what-is-pro-bono/. Accessed February 5, 2019.

5. Nibbe NA. Beyond the free clinics origin myth: Reconsidering free clinics in the context of 1960s and 1970s social movements and radical health activism, University of California, San Francisco; 2012.

6. Jacobs L, Lamoureux N. The free clinic movement: America's best kept healthcare secret. Retrieved at: https://www.medscape.com/viewarticle/770688. Accessed February 5, 2019.

7. Haight Ashbury Free Clinics. Retrieved at: https://www.healthright360.org/agency/haight-ashbury-free-clinics. Accessed February 5, 2019.

8. Schwartz JL. First national survey of free medical clinics 1967-69. HSMHA Health Rep. 1971;86(9):775-787. [PMID: 5129288] 
9. Darnell JS. Free clinics in the united states: A nationwide survey. Arch Intern Med. 2010;170(11):946-953. [PMID: 20548006]

10. Simpson SA, Long JA. Medical student-run health clinics: Important contributors to patient care and medical education. J Gen Intern Med. 2007;22(3):352-356. [PMID: 17356967]

11. Smith S, Thomas R, III, Cruz M, Griggs R, Moscato B, Ferrara A. Presence and characteristics of student-run free clinics in medical schools. JAMA. 2014;312(22):2407-2410. [PMID: 25490333]

12. Beck E. The UCSD student-run free clinic project: Transdisciplinary health professional education. J Health Care Poor Underserved. 2005;16(2):207-219. [PMID: 15937383]

13. Rebholz CM, Macomber MW, Althoff MD, Garstka M, Pogribny A, Rosencrans A, et al. Integrated models of education and service involving community-based health care for underserved populations: Tulane student-run free clinics. South Med J. 2013;106(3):217-223. [PMID: 23462491]

14. Ojeda VD, Eppstein A, Lozada R, Vargas-Ojeda AC, Strathdee SA, Goodman D, et al. Establishing a binational student-run free-clinic in tijuana, mexico: A model for us-mexico border states. J Immigr Minor Health. 2014;16(3):546548. [PMID: 23371839]

15. Wang T, Bhakta H. A new model for interprofessional collaboration at a student-run free clinic. J Interprof Care. 2013;27(4):339-340. [PMID: 23368712]

16. Moskowitz D, Glasco J, Johnson B, Wang G. Students in the community: An interprofessional student-run free clinic. J Interprof Care. 2006;20(3):254-259. [PMID: 16777793]

17. Farlow JL, Goodwin C, Sevilla J. Interprofessional education through service-learning: Lessons from a student-led free clinic. J Interprof Care. 2015;29(3):263-264. [PMID: 25565371]

18. Seif G, Coker-Bolt P, Kraft S, Gonsalves W, Simpson K, Johnson E. The development of clinical reasoning and interprofessional behaviors: Service-learning at a student-run free clinic. J Interprof Care. 2014;28(6):559-564. [PMID: 24865993]

19. Palombaro KM, Dole RL, Lattanzi JB. A case report of a student-led pro bono clinic: A proposed model for meeting student and community needs in a sustainable manner. Phys Ther. 2011;91(11):1627-1635. [PMID: 21868614]

20. Johnson MP, Maritz CA, Lefever G. The mercy circle of care: An interdisciplinary, multi-institutional collaboration to promote community health and professional education. J Phys Ther Educ. 2006;20(3):73-79.

21. American Physical Therapy Association. Professionalism in physical therapy: Core values. Retrieved at: https://www.apta.org/uploadedFiles/APTAorg/About_Us/Policies/BOD/Judicial/ProfessionalisminPT.pdf. Accessed February 5, 2019.

22. American Physical Therapy Association. Code of ethics for the physical therapist. Retrieved at: https://www.apta.org/uploadedFiles/APTAorg/About_Us/Policies/HOD/Ethics/CodeofEthics.pdf. Accessed April 3, 2019.

23. O'Brien SR, Bulas M, Metcalfe A, Mix Z, Richert T, Wagner R. Meaningful functional change achieved from physical therapy provided in a student-run pro bono clinic. J Allied Health. 2017;46(3):138-142. [PMID: 28889162]

24. Stickler K, Sabus C, Gustafson H, Kueser M, Lavaveshkul B, Denney L. Pro-bono service through student-run clinics: How does physical therapy measure up? J Allied Health. 2016;45(3):207-211. [PMID: 27585617]

25. Commission on Accreditation in Physical Therapy Education. Retrieved at: http://www.capteonline.org/home.aspx. Accessed February 7, 2019.

26. The Suitcase Clinic. Retrieved at: https://www.suitcaseclinic.org/history. Accessed February 10, 2019.

27. Society of Student Run Free Clinics. Retrieved at: http://www.studentrunfreeclinics.org/. Accessed September 9, 2018.

28. The Pro Bono Network. Retrieved at: http://theprobononetwork.com. Accessed February 10, 2019.

29. Goodell S, Cohen JT, Neumann PJ. The cost savings and cost-effectiveness of clinical preventive care. The Synthesis Project: New Insights from Research Results. Robert Wood Johnson Foundation; 2009. Retrieved at: http://www.walkboston.org/sites/default/files/Cost $\% 20$ savings $\% 20$ and\%20 costeffectiveness\%20of\%20clinical\%20preventive\%20care_0.pdf. Accessed April 3, 2019.

30. Black J, Palombaro K, Dole R. Student experiences in creating and launching a student-led physical therapy pro bono clinic: A qualitative investigation. Phys Ther. 2013;93(5):637-648. [PMID 23431216].

31. Porretta D, Black J, Palombaro K, Erdman E. Influence that service in a pro bono clinic has on a first full-time physical therapy clinical education experience. Internet J Allied Health Sci Pract. 2017;15(1):11.

32. Black J, Bauer K, Spano G, Voelkel S, Palombaro K. Grand rounds: A method for improving student learning and client care continuity in a student-run physical therapy pro bono clinic. Journal of the Scholarship of Teaching and Learning. 2017;17(3):68-88. Retrieved at: https://doi.org/10.14434/v17i3.21158. Accessed April 3, 2019.

33. Crandell C, Wiegand M, Brosky J. Examining the role of service-learning on development of professionalism in doctor of physical therapy students: A case report. J Allied Health. 2013;42(1):e25-32. [PMID: 23471290] 
34. Wise HH, Yuen HK. Effect of community-based service learning on professionalism in student physical therapists. J Phys Ther Educ. 2013;27(2):58-64.

35. Furze J, Black L, Peck K, Jensen GM. Student perceptions of a community engagement experience: Exploration of reflections on social responsibility and professional formation. Physiother Theory Pract. 2011;27(6):411-421. [PMID: 20946070]

36. O'Brien SR, Byrd N, Derleth O, Morsch E, Sabatose L, Smith A. Quality of life and function in patients with chronic stroke receiving physical therapy in a student-run pro-bono clinic. Physical Therapy Journal of Policy, Administration and Leadership. 2018;18(3):29-35. 